\title{
Towards a Systemic Assessment of Gendered Energy Transition in Urban Households
}

\author{
Josephine Kaviti Musango * and Andrea M. Bassi
}

check for

updates

Citation: Musango, J.K.; Bassi, A.M. Towards a Systemic Assessment of Gendered Energy Transition in Urban Households. Energies 2021, 14, 7251. https://doi.org/10.3390/en14217251

Academic Editor: David Borge-Diez

Received: 12 October 2021

Accepted: 26 October 2021

Published: 3 November 2021

Publisher's Note: MDPI stays neutral with regard to jurisdictional claims in published maps and institutional affiliations.

Copyright: (c) 2021 by the authors. Licensee MDPI, Basel, Switzerland. This article is an open access article distributed under the terms and conditions of the Creative Commons Attribution (CC BY) license (https:// creativecommons.org/licenses/by/ $4.0 /)$.
School of Public Leadership, Stellenbosch University, Stellenbosch 7600, South Africa; andrea.bassi@ke-srl.com

* Correspondence: jmusango@sun.ac.za

\begin{abstract}
Assessment of gendered energy transition at an urban scale has emerged as a challenging issue for researchers, policy makers and practitioners. With municipalities becoming players in the energy markets, their involvement raises policy issues that need to be better assessed in supporting gendered energy transition. This paper, therefore, contributes to gendered energy transition assessments at urban household level from a policy maker perspective. We developed a system dynamics model to assess the effects of urban energy policy interventions on household energy consumption and gendered measures using Drakenstein Municipality as a case study. The study used secondary data from various sources for the model parameters. We tested three hypothetical policy scenarios: the business-as-usual, the energy subsidy policy and the energy efficiency policy. The results show that understanding the changes in urban household energy consumption and gendered measures due to energy transition interventions is essential for urban policy planning. The energy subsidy policy scenario was observed to increase total energy consumption but also resulted in socio-environmental impacts that might increase inequality and impair human health. Urban household energy transition interventions need to consider a systems approach to develop decision support tools that capture the cross-sector impacts and inform the development of interventions that promote gendered household energy transition.
\end{abstract}

Keywords: household energy transition; gender mainstreaming; urban energy planning; energy services; urban Africa

\section{Introduction}

The need for an energy transition is apparent in Sustainable Development Goal (SDG) 7, which stipulates access to clean, affordable and sustainable energy for all and in the International Energy Agency [1] report, which provides a roadmap for the energy transition to net-zero by 2050. Further, growing urbanisation has sparked renewed interest in urban household energy transition and the need to understand household demand and consumption patterns. Historically, energy is not considered in urban planning and is only integrated at the end of the pipe $[2,3]$. Further, the methods used for national energy planning and forecasting may not apply in urban household policy.

On the one hand, the energy transition can be seen as a set of complex, multidimensional processes that affect the generation, distribution, storage and use of energy emerging from changes in policies, regulations, business plans, economies and societies [4-7]. This energy transition perspective is what Blazquez et al. [7] refer to as switching from an economic system that depends on specific energy sources and technologies to a different economic system that depends on other energy sources and technologies. In urban households, studies have examined the energy transition from the perspective of adoption of appropriate appliances or technologies by the majority of users [8].

On the other hand, the energy transition can be examined within the larger context of sustainable development. García-García et al. [9] conceptualise the energy transition in relation to sustainable development in three layers that provide the larger context in 
which an energy system operates. They refer to the first (outer) layer as the process of shifting from one ecological regime to another more sustainable ecological regime; the second (middle) layer as the process of shifting from a high-carbon energy system to a low-carbon, renewable energy mix; and the third (inner) layer as the place where the social injustices in the energy sector are addressed. These three layers are interlinked, and together they focus on (i) making the transition more sustainable; (ii) making the transition more just; (iii) encouraging justice in transition research agendas and frameworks to identify problems and offer solutions; and (iv) guiding transition processes.

Several studies have highlighted that the energy transition is not only about technical solutions, e.g., [10,11], but is also enabled by policies, e.g., [7], and shaped by the application domain of the technology relating to user practices [12]. Despite these acknowledgements, social justice issues in the third layer of the García-García et al. [9] framework are still lacking. They are far less popular in the design and implementation of the energy transition. In particular, Lieu et al. [13] suggest that gender aspects in energy transition studies are unexplored or implicit. They explored three different pathways to frame the gender perspective in the energy transition. The first perspective is the mainstream energy pathway, consisting of conventional fuels with high carbon content and male-dominated energy institutions. The second perspective is the off-stream pathway, which considers niches for low-carbon technologies and different roles and needs for males and females across policies. The third perspective is the transformative pathway, which considers low-carbon technologies and integrates all gender perspectives in policy decision making.

While these pathways are useful contributions of the gendered energy perspective at the policy level, major gaps exist in implementing gendered perspectives for policy, industry and end-users (households, industry and government). In particular, energy is rarely integrated into urban planning, yet urban areas are becoming relevant in supporting household energy transition pathways. The transformative pathway requires addressing practical issues related to (i) how gender is framed in urban policy making; (ii) how the gendered energy perspective is measured at an urban household scale; (iii) how the gendered assessment is incorporated into the urban household energy transition; and (iv) how the gendered perspective is considered in energy services provision in urbanising Africa where energy insecurity persists.

This paper does not answer all these questions. It rather provides an exploration of the question: What are the gendered measures, and the economic and socio-environmental effects of policy interventions that promote urban household energy transition? This question is addressed by developing a gendered urban household energy transition (GUHET) model to analyse the effects of hypothetical policy interventions-energy subsidy and energy efficiency measures-on selected energy transition indicators, using the case study of Drakenstein Municipality in South Africa. The paper contributes to filling the gap in the literature regarding assessments of the gendered urban household energy transition with quantitative studies using a systems approach [14,15] and open box approaches that consider households as dynamic systems [16].

\section{Urban Household Energy Transition}

The gendered perspective on the energy transition at an urban household level is a multi-dimensional and non-linear problem. Urban planners need to manage the competing demands of the energy trilemma, which according to the World Energy Council [17] includes energy security, environmental sustainability and energy equity. Energy security is the ability to meet current and future demand, energy equity is the ability to provide universal access to all at an affordable price, and environmental sustainability is the ability to minimise environmental impacts through energy efficiency and low-carbon transition [17]. Building on the energy trilemma, the gendered energy transition process at the urban household level is characterised by endogenous shifts in energy sources, energy services and dwelling types, influencing the devices utilised in households [14,18]. 
Knowledge of the household energy transition pattern is becoming relevant to support global, national and local agendas relating to low-carbon transition [16]. However, a lack of coherent theoretical background, data and assessments hinders such knowledge. Urbanisation is a key factor influencing household energy transition in developing countries, particularly in Africa, where urbanisation is expected to grow the fastest between 2030 and 2050 [19]. The effects of urbanisation on the energy transition can be examined empirically. It is not intuitively clear how interventions to promote the energy transition could influence household energy consumption.

It is therefore becoming relevant to assess the effects of policy interventions on economic, social and environmental indicators related to the household energy transition. Further, open box approaches to household energy transition [16] that consider gendered measures can improve energy access and energy security and reduce environmental impacts. Because the urban household energy transition is a multi-faceted problem, we utilise system dynamics to develop a generic sub-systems model structure applied in Drakenstein Municipality.

The application of system dynamics in the energy transition is not new. It has been applied by Naill [20] to explore the transition from coal to oil in the USA. However, its application to explore gendered energy transition is limited. In their review of models for energy transition pathways, Bolwig et al. [13] consider system dynamics as a tool that can endogenously capture the analysis of transition pathways. Similarly, Selvakkumaran and Ahlgren [21] reviewed the application of system dynamics in the local energy transition. They show that the "local energy transition" is characterised by a geographic scope in a specific context, and in some cases, is undertaken in collaboration with energy communities. They define 'local' as "responsible for a small area, especially of a country". A case study in an urban area can be categorised as local. However, the gender aspect is the missing gap in all the papers that Selvakkumaran and Ahlgren [21] reviewed. Similarly, Destyanto et al. [22] explored the effect of a government programme in Indonesia for the household to transition from kerosene to liquefied petroleum gas (LPG). Despite the wide application of system dynamics in energy transition research, the gender aspect is often ignored, and there is limited research to support urban policy on household energy transition.

Emerging research contributing to system dynamics in gendered energy transition includes that by Batinge et al. [18] and Musango [23]. Batinge et al. [18] explored dynamic feedback loops when providing energy services security at a household level. Energy services are the functions that energy provides to fulfil the desired state, indicating levels of satisfaction [24,25], and these services include lighting, cooking, refrigeration, space heating and cooling [26].

This paper contributes to the urban household energy transition in two ways. Firstly, in terms of methodology, system dynamics is used to explore the effects of energy transition policy interventions on social, economic and environmental indicators. In addition, gendered measures relevant to informing the urban household energy transition were highlighted. The model incorporates cross-sector effects that assess the urban household energy transition as a complex non-linear process evaluated to inform and support urban policy and planning.

Secondly, in terms of scope, the urban household energy transition is developed using the case study of Drakenstein Municipality. Although numerous household energy surveys have been conducted, they remain stand-alone assessments and focus on what Raven et al. [16] refer to as closed box approaches. The ability to utilise a system dynamics model that can be customised to explore various cases is essential. The generic sub-systems model structure can be customised for use in other urban household case studies.

\section{Drakenstein Municipality}

Drakenstein Municipality is situated in the Western Cape province of South Africa, with a total area of $1538 \mathrm{~km}^{2}$. In 2016, the municipality had a population of 300,991 repre- 
senting 71,686 households [27]. The municipality is categorised as a secondary city [28]. A secondary city generally describes the second tier in the hierarchy of cities after the primary level. The definition of a secondary city can be based on population size, and economic, political and administrative area relevance within a region or country [29]. According to UN Habitat [30], a secondary city is an urban area with a population of between 100,000 and 500,000 people. Many of the studies in the literature focus on primary cities, while secondary cities are often neglected, although their role in managing urbanisation is recognised [29].

Drakenstein's gross value added (GVA) was 19.8 billion Rand in 2016 [31,32]. A large proportion of households, $90.3 \%$, reside in a formal structure, and the proportion of femaleheaded households is $34.1 \%$ [33]. Although $98.4 \%$ of Drakenstein households had access to electricity in 2016 [27], about 2200 households [34], mostly in informal settlements, are still not connected to the grid. Other statistics have indicated that $13.2 \%$ of the households lived in informal dwellings in 2018, translating to about 8576 households. Although data inconsistencies were evidenced, the Drakenstein Municipality household electricity profile indicates that $3.8 \%$ of households do not have access to electricity [31].

One of the energy challenges in Drakenstein is diversifying the energy mix and the energy costs [31]. The households' energy mix includes electricity, paraffin, LPG and wood [28]. According to Sustainable Energy Africa [28], the estimated total energy consumption in Drakenstein is about 6 million gigajoules, of which the residential sector consumes about $15 \%$. The use of paraffin as an energy source also increased from $2.3 \%$ in 2011 to $2.9 \%$ in 2016 [31]. The energy needs of the informal dwelling households are still based on traditional fuels. A particular concern is the increasing illegal connections and the need to seek alternative energy technology solutions to improve access.

Drakenstein Municipality is one of the six municipalities in the Western Cape that can generate or buy its own electricity. The municipality has a policy for embedded electricity generation adopted in June 2019 and has a co-generation tariff of 0.5077 Rand $/ \mathrm{kWh}$ [35]. The energy transition opportunities seen as key at the municipal level include small-scale embedded generation, energy storage and energy efficiency [36].

\section{Method}

System dynamics is a field developed by Jay Forrester in the late 1950s. Various studies in system dynamics, e.g., [17-20], define system dynamics using technical terms. From a practical point of view, system dynamics can be considered "an integrated and quantitative (modelling) approach utilised to understand situations for complex real-world issues to guide decision making over time for achieving sustainable long-term solutions" (System Dynamics Class of 2012, School of Public Leadership, see [21]).

System dynamics was initially applied to corporate problems and was later expanded to other issues related to sustainability. A well-renowned application was by the Club of Rome, which led to the publication of The Limits to Growth [22], led by Donella Meadows, and later, Beyond the Limits [23].

In this study, we developed a generic sub-systems model for analysing gendered urban households' energy transition (Figure 1). The generic sub-systems structure allows evaluation of the household energy transition in the context of interactions with urban policy decision makers and the effects of interventions on key indicators. Unlike the traditional approaches to the energy transition that focus on the supply side, the model developed in this study focuses on urban household consumption. In examining the household energy transition, it is essential not only to evaluate it in terms of technology switch but also to consider the social, economic and environmental context in which it is taking place.

Various studies have highlighted factors that influence household energy transition. Kowsari and Zerriffi [36] provide endogenous and exogenous factors. Endogenous factors could have any of the following three characteristics: economic such as income and expenditure; non-economic such as household size, age and gender; and behavioural and 
cultural characteristics such as preferences, lifestyle and ethnicity [37]. Exogenous factors could include physical location or climatic conditions, policies, energy supply factors such as affordability, availability and access, and energy device characteristics such as conversion efficiency, cost and ease of operation [37]. Depending on the method of assessment and scale of application, the exogenous factors could be examined endogenously, particularly when considering open box approaches [16] or if the modelling is undertaken from the perspective of a household as a decision maker. For example, in this study, affordability is modelled endogenously because the scale of application is urban households from the perspective of an urban decision maker. Similarly, investment in energy transition can be examined endogenously within a household when modelling takes the household as a decision maker.

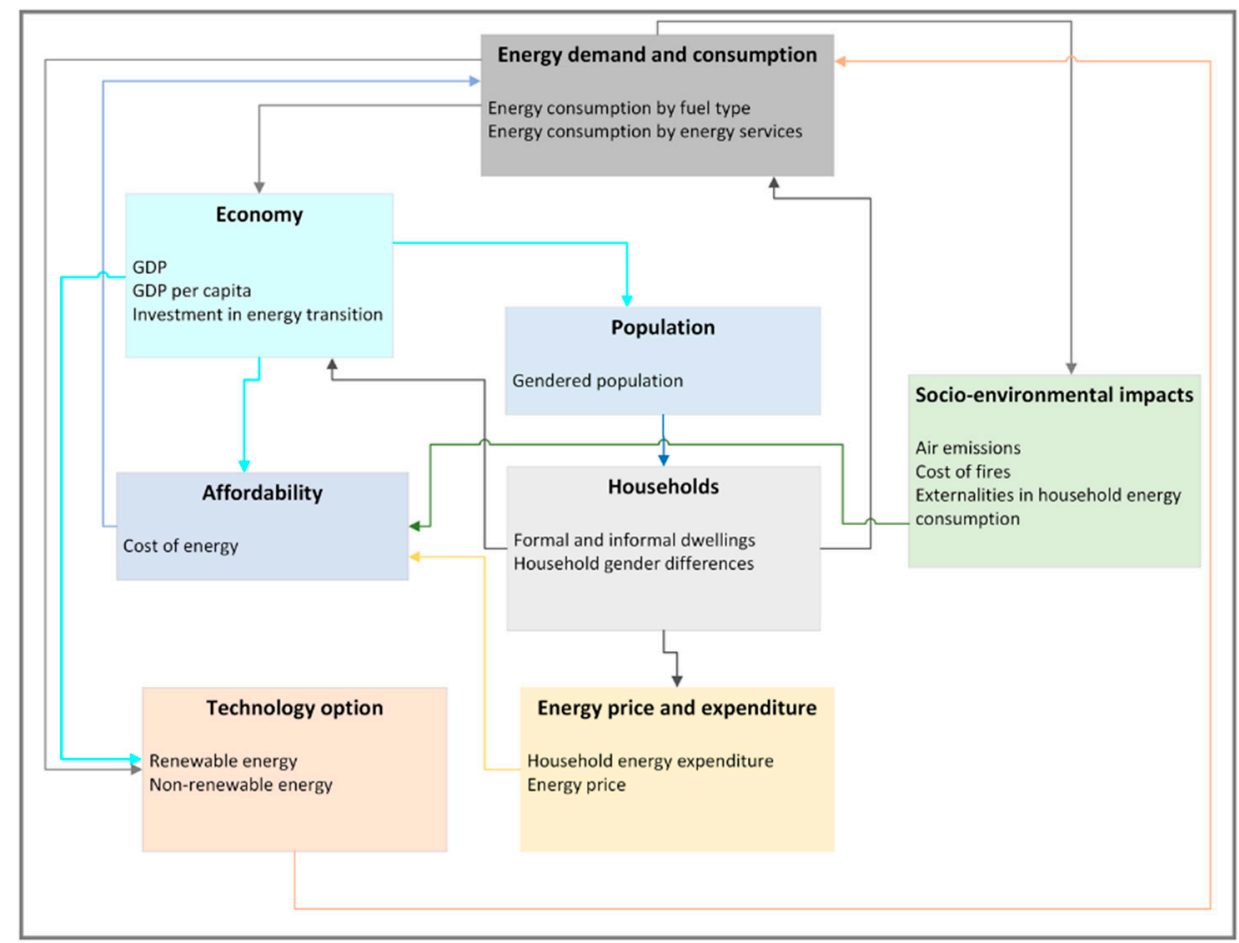

Figure 1. Generic sub-systems structure for analysing gendered urban households' energy transition. Source: Authors.

Based on the sub-systems in Figure 1, we developed a gendered urban household energy transition (GUHET) model using Vensim (DSS) version 9, which is one of the system dynamics simulation software programs. Vensim provides the ability to capture the real-world system, with causal tracing of the structure and behaviour of a system, and has subscripts, optimisation and Monte Carlo sensitivity capabilities.

\subsection{Causal Loop Diagram}

Figure 2 shows three aggregated feedback loops representing the dynamic hypothesis for the study. These are the energy demand and consumption loop, the affordability loop and the socio-environmental impact loop, representing the energy transition trilemma regarding energy security, energy affordability and environmental sustainability.

The energy demand and consumption loop (R1), which is a reinforcing loop, indicates that an increase in the number of households in the urban area increases the demand for household energy services such as lighting, cooking, refrigeration, water heating and space heating. The increased demand for energy services leads to higher energy consumption and increased GVA. With improved GVA, employment opportunities emerge, leading to the attractiveness of the urban area, thereby increasing migration and ultimately the households in the urban area. 


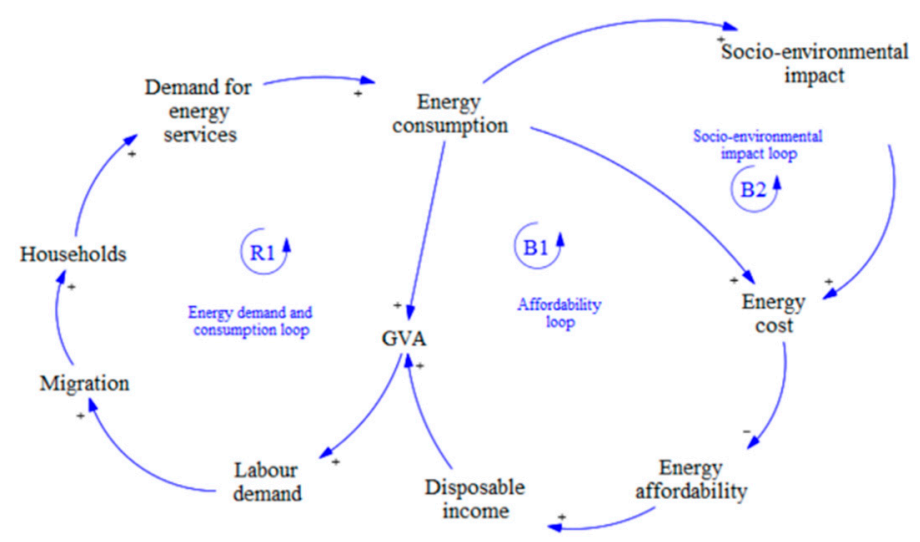

Figure 2. Aggregated dynamic hypothesis of the gendered urban household energy transition. Source: Authors.

The affordability loop (B1), which is balancing, is a much longer loop. It shows that increased energy consumption leads to a rise in energy cost, which reduces energy affordability. With decreased affordability, the disposable income is reduced, decreasing the GVA and, ultimately, the number of people migrating into the urban area. With fewer households, energy demand and consumption are reduced. The affordability loop is supported by empirical evidence in Wang et al., [38], who found that urbanisation without a corresponding increase in GVA reduced aggregate consumption.

The socio-environmental impact loop (B2) is an even longer loop. It shows that socioenvironmental impacts from energy consumption increase the cost to society, ultimately increasing the cost of energy. Some of these impacts include air emissions and health risks related to the use of certain fuels such as paraffin and wood.

\subsection{Mathematical Model}

The mathematical model was categorised into eight sub-models, namely, the economy, population, households, household energy demand and consumption, energy affordability, energy price and expenditure, technology options and socio-environmental impact submodels, following the generic sub-systems structure in Figure 1. The mathematical model also followed a similar model structure to Bassi [39] but was extended to include gendered measures. The model was developed within the timeframe 2016 to 2040 because most data were available for 2016. The end year 2040 aligns with OneCape 2040, which envisions a transition towards an integrated and resilient economic future for the Western Cape region [40]. However, reference to 2011 data was used in some cases. The study used various sources to obtain the parameter data utilised in the GUHET model, presented in Table S1 of the Supplementary Materials. Additionally, not all parameters' data were available for Drakenstein Municipality. We therefore developed a transparent data collection criterion, described in Table S1 of the Supplementary Materials.

\subsubsection{Economy Sub-Model}

The economic growth of a local government influences the energy transition in the economy and households. Earlier studies have demonstrated the relationship between economic development and energy use [41,42]. Consumption of energy services influences economic growth, represented by GVA.

According to the Drakenstein Integrated Economic Growth Strategy [32], emphasis is placed on improving the economic status of the municipality. The economy sub-model represents the GVA of Drakenstein Municipality, which influences labour demand, enabling employment creation. Increased employment improves disposable income and ultimately increases the changes in the GVA. Disposable income is one of the factors that determine household energy consumption. 
A key variable as a gendered indicator in the economy sub-model is the gendered labour force. With information on the proportion of the labour force who are male or female, gendered labour force can be estimated. What was excluded is the representation of the gendered labour force by category, either skilled, semi-skilled or low-skilled, because disaggregated gendered input parameters were lacking.

\subsubsection{Population Sub-Model}

The population is one of the key determinants of household demand. The population sub-model represents the population of Drakenstein Municipality, categorised by age and sex. The population sub-model captures the gender indicator relevant for policy, which is represented by the gendered total population variable. The key stock is population, which is increased by births and net migration, and decreased by deaths. Immigration mainly occurs internally, whereby the population moves from rural to urban areas.

\subsubsection{Household Sub-Model}

Assessing household transition through the lens of different scales emphasises the role of households in the transition process and outcomes [43]. Gender relations within households are a key determinant of the household energy transition for specific energy services [44]. The household head influences the energy use and technology choice decisions [44].

The household sub-model represents the number of households in Drakenstein Municipality. The main stock is households, which captures the number of households, and the gendered households were estimated. While the population sub-model captured gender by sex, the household sub-model captured gender by household head, who makes most of the household decisions. The household head influences demand for energy fuels and the choices in fuel consumption to meet household energy services.

Although from an urban planner point of view, households are the target for policies, it is possible to explore the internal workings of households using specific cases to inform and support specific energy transition assessments.

The type of dwelling in which the household resides influences the fulfilled energy services and the energy fuel choices that can be considered. The household sub-model, therefore, categorised households by dwelling type broken down into five groups concerning energy issues: formal electrified, formal non-electrified, informal electrified, informal non-electrified and backyarders. These are the categories relevant in exploring energy access, energy security and socio-environmental impacts that arise in different dwelling types due to energy transition interventions.

\subsubsection{Household Energy Demand and Consumption Sub-Model}

Households use different fuel types such as biomass, kerosene, LPG and electricity, determined by changing incomes, energy prices and demographics. Urban household energy transition, although not clearly understood, can occur through a shift from one fuel type to another or the use of efficient fuels and technologies [41,45].

The household energy demand and consumption sub-model captures the demand for and consumption of household energy services by fuel type. The study explored six energy services, namely, lighting, electronics, white appliances, heating, water heating and cooking, and four fuel types, namely, biomass, paraffin, LPG and electricity.

The World Health Organization [46] considers electricity and LPG as clean fuels, unlike fuels such as biomass and paraffin, which have incomplete combustion. However, the technology utilised to generate electricity also influences its socio-environmental impacts. Despite most households being connected to the grid in Drakenstein, the households still make use of other fuel types to meet their energy services. These include biomass, paraffin and LPG. Although paraffin is an alternative to biomass burning, paraffin fumes are toxic and poisonous when accidental ingestion occurs. 
Energy efficiency is the key stock in household energy demand and consumption, which are influenced by improved energy efficiency. The main urban policy concern is to provide energy services efficiently.

\subsubsection{Energy Affordability Sub-Model}

Energy affordability is a key determinant of a household's ability to transition from one fuel type to another to meet household energy services [44]. Affordability can be determined by the energy price, the price of competing fuels and the costs of appliances associated with the fuel $[44,47]$. The energy affordability sub-model represents the preference for purchasing one fuel type relative to an alternative. Energy affordability is a key stock influenced by annual changes in affordability. Energy affordability influences demand for specific fuel types in each of the household dwelling types.

\subsubsection{Energy Price and Expenditure Sub-Model}

The energy price of the different fuel types influences the household expenditure on energy, which in turn affects affordability. In the South African context, the energy price is determined exogenously rather than determined by the dynamics of energy supply and demand. Energy market trends in South Africa show increasing energy prices while energy demand has been declining [36].

\subsubsection{Technology Options Sub-Model}

The technology options sub-model represents the share of demand for energy that can be serviced using off-grid renewables for energy services such as water heating and lighting. The energy price of the different fuel types influences the household's expenditure on energy, which in turn affects affordability.

Access to technology alone does not determine the transition to cleaner technologies. Hence, understanding household energy consumption behaviours is necessary. Leach [41] shows that energy transition is driven not by the desire for modern technology options but rather by the socio-economic changes that support overcoming the barriers. A policy can incentivise household energy transition through interventions that address the fuel cost, hence improving affordability [44]. However, technology or policy options for household energy transition need to consider the household energy services and how introducing new technologies or policies may result in changes in the use of the different fuel types.

\subsubsection{Socio-Environmental Impact Sub-Model}

Household energy use to fulfil energy services contributes to socio-environmental impacts. The use of biomass and paraffin is commonly attributed to health risks and opportunity costs related to air pollution, burns and ingestion [48].

The socio-environmental impact sub-model estimates key indicators for social, health and environmental externalities in using certain fuel types. These indicators include the social cost of carbon emissions, fires resulting from paraffin, biomass and electricity consumption, and burns from the use of paraffin. Awareness of how policy interventions affect household energy consumption and, ultimately, the socio-environmental impacts was the goal of this study, considering gendered measures. Understanding the impact of energy transition interventions on urban household energy consumption contributes to identifying the potential impacts on society and the environment.

\subsection{GUHET Scenarios}

Household energy transition can be managed through policies to meet broader political objectives. These objectives include: (i) building sustainable cities and communities to improve the living standards of the urban population and to reduce air emissions and health-related risks; and (ii) reducing unsustainable use of unclean fuels $[15,41]$. Subsidies to reduce the price of modern fuels have been used as an accelerator of energy transition 
by several countries [41]. Similarly, implementing energy efficiency measures is one of the key drivers supporting household energy transition [49].

From an urban planning perspective, three hypothetical policy scenarios were tested to examine their effect on energy transition indicators. These were business as usual (BAU), energy efficiency policy (EEP) and energy subsidy policy (ESP). The BAU assumes the current policy situation prevails. Economic development is emphasised, which in some ways does not favour a sustainable transition. Relevant urban policy measures that relate to population, households and GVA for Drakenstein Municipality were presented.

The EPP scenario implements an additional energy efficiency of $1 \%$ in 2022 , which is removed in 2025.

The ESP scenario introduces an energy subsidy of $20 \%$ in 2020 , which is removed in 2025. Energy subsidies can be pursued to achieve specific policy goals, such as: providing affordable energy for low-income members of society, correcting markets for unpriced externalities, inducing technology learning and driving down the costs of new technologies, reducing import dependence, enhancing energy security and creating new economic activity and jobs [50]. The energy subsidy hypothesis used in this study was informed by the COP26 Energy Transition Council, which aims to find speedy solutions to support clean technology transition in the power sector by 2030.

\section{Results}

Based on the simulation of the BAU, EEP and ESP scenarios, the results are presented for: (i) changes in households; (ii) changes in gross value added; (iii) changes in households by dwelling type; (iv) changes in energy consumption by fuel type; and (v) changes in socio-environmental impacts.

\subsection{Changes in Households}

The changes in households in the BAU scenario reach 110,344 people in 2040, which is about a $29 \%$ increase relative to BAU in 2021 (Figure 3). The number of households by gender of the head is indicated in the gendered households. Within Drakenstein Municipality, most of the households are male-headed, which reaches 73,268 households in 2040 while female-headed households reach 37,076. Understanding changes in households supports medium to long-term urban planning to ensure energy security, affordability and sustainability.

Disaggregated gendered household measures provide an indication of who manages the overall household decision making. Although the results show a larger proportion of male-headed households in Drakenstein, specific case study interventions within the municipality may differ. Evidence from the Groenheuwel informal settlement in Drakenstein Municipality showed that the majority of sampled households were female-headed. Kovacic et al. [51] similarly found that the majority of sampled households in three informal settlements in South Africa, Kenya and Uganda were female-headed. The implication is that energy transition interventions would differ by dwelling type within an urban area. Further exploration will involve assessment of the gender of the head by household dwelling type and the gender of the person responsible for energy-related decisions.

\subsection{Changes in Gross Value Added}

The GVA in the EEP and ESP scenarios relative to the BAU scenario increases marginally. By 2040 , the GVA increases by $28.74 \%$ in the ESP and $28.75 \%$ in the EEP scenarios, relative to BAU in 2021 (see Figure 4). Both the EEP and ESP scenarios reduce energy costs, which improves affordability, which ultimately improves gross value added albeit only slightly. The year-on-year gross value added change in 2040 relative to BAU is $0.05 \%$ for the ESP and $0.07 \%$ for the EEP scenarios. In contrast, Wang et al. [38] present evidence of urbanising areas in sub-Saharan Africa that show a decline in aggregate energy consumption as economic growth decreases. The decline in aggregate consumption may indicate energy insecurity due to unfulfilled household energy services. The implication for urban 
household energy transition is that marginal changes in the GVA relative to changes in the population or households may decrease aggregate household energy consumption.

TOTAL HOUSEHOLDS
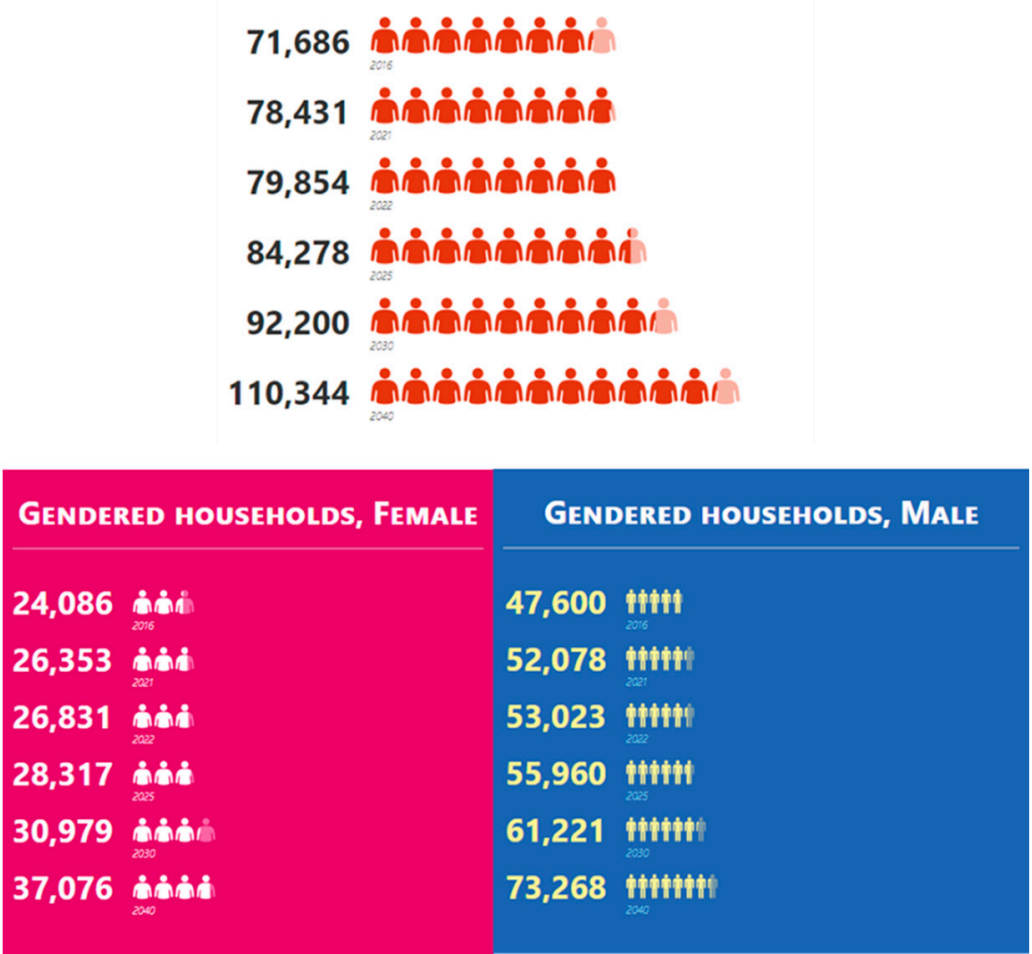

Figure 3. Total households and gendered households, BAU scenario. Source: Authors.

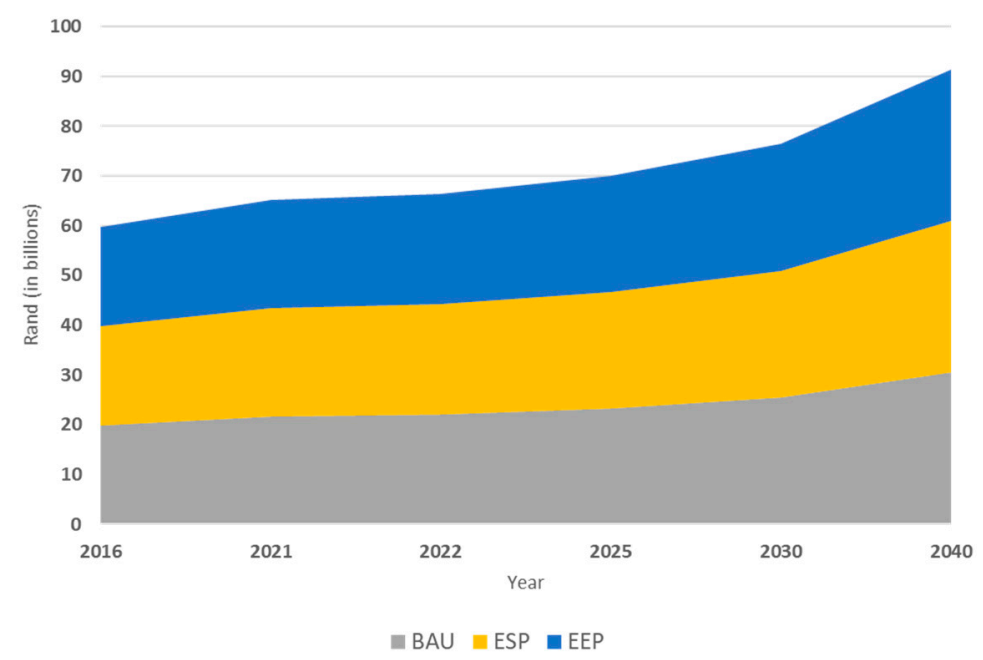

Figure 4. GVA in the BAU, ESP and EEP scenarios. Source: Authors.

\subsection{Changes in Households by Dwelling Type}

Introducing an energy subsidy shows small changes in the total number of households relative to the BAU scenario, as indicated in Figure 5. The formal electrified households continue to increase even after the subsidy removal, reaching $92.09 \%$ by 2040 , while the other dwelling types decline with the introduction of the subsidy policy. This observation indicates that an intra-dwelling shift in households occurs, whereby households in formal electrified dwellings increase while the other dwelling types decrease (Figure 5). 


\begin{tabular}{|c|c|c|c|c|c|c|c|c|c|}
\hline Time (Year) & 2016 & 2017 & 2021 & 2022 & 2023 & 2024 & 2025 & 2030 & 2040 \\
\hline \multicolumn{10}{|c|}{ Share of households by dwelling type } \\
\hline \multicolumn{10}{|c|}{ [FORMAL ELECTRIFIED] } \\
\hline Energy Subsidy & $90.30 \%$ & $90.31 \%$ & $90.52 \%$ & $90.68 \%$ & $91.07 \%$ & $91.30 \%$ & $91.43 \%$ & $91.54 \%$ & $92.09 \%$ \\
\hline BAU & $90.30 \%$ & $90.31 \%$ & $90.52 \%$ & $90.59 \%$ & $90.65 \%$ & $90.71 \%$ & $90.78 \%$ & $91.09 \%$ & $91.70 \%$ \\
\hline \multicolumn{10}{|c|}{ [FORMAL NON-ELECTRIFIED] } \\
\hline Energy Subsidy & $0.10 \%$ & $0.10 \%$ & $0.10 \%$ & $0.10 \%$ & $0.09 \%$ & $0.09 \%$ & $0.09 \%$ & $0.09 \%$ & $0.08 \%$ \\
\hline BAU & $0.10 \%$ & $0.10 \%$ & $0.10 \%$ & $0.10 \%$ & $0.10 \%$ & $0.10 \%$ & $0.10 \%$ & $0.09 \%$ & $0.09 \%$ \\
\hline \multicolumn{10}{|c|}{ [INFORMAL ELECTRIFIED] } \\
\hline Energy Subsidy & $1.00 \%$ & $1.00 \%$ & $0.98 \%$ & $0.96 \%$ & $0.92 \%$ & $0.90 \%$ & $0.88 \%$ & $0.87 \%$ & $0.82 \%$ \\
\hline BAU & $1.00 \%$ & $1.00 \%$ & $0.98 \%$ & $0.97 \%$ & $0.96 \%$ & $0.96 \%$ & $0.95 \%$ & $0.92 \%$ & $0.86 \%$ \\
\hline \multicolumn{10}{|c|}{ [INFORMAL NON-ELECTRIFIED] } \\
\hline Energy Subsidy & $7.80 \%$ & $7.79 \%$ & $7.62 \%$ & $7.50 \%$ & $7.18 \%$ & $7.00 \%$ & $6.90 \%$ & $6.80 \%$ & $6.36 \%$ \\
\hline BAU & $7.80 \%$ & $7.79 \%$ & $7.62 \%$ & $7.57 \%$ & $7.52 \%$ & $7.47 \%$ & $7.42 \%$ & $7.17 \%$ & $6.68 \%$ \\
\hline \multicolumn{10}{|l|}{ BACKYARDERS } \\
\hline Energy Subsidy & $0.80 \%$ & $0.80 \%$ & $0.78 \%$ & $0.77 \%$ & $0.73 \%$ & $0.72 \%$ & $0.70 \%$ & $0.69 \%$ & $0.65 \%$ \\
\hline BAU & $0.80 \%$ & $0.80 \%$ & $0.78 \%$ & $0.77 \%$ & $0.77 \%$ & $0.76 \%$ & $0.76 \%$ & $0.73 \%$ & $0.68 \%$ \\
\hline
\end{tabular}

Figure 5. Share of households by dwelling type. Source: Authors.

Exploring the year-on-year changes of the intra-household shifts shows that the largest change in households by dwelling type occurs in 2025 (Figure 6). Although the decline in other dwelling types appears large, the absolute value of decline is more or less the same as the value of the increase in formal electrified dwellings, which is $0.68 \%$ in 2025 .

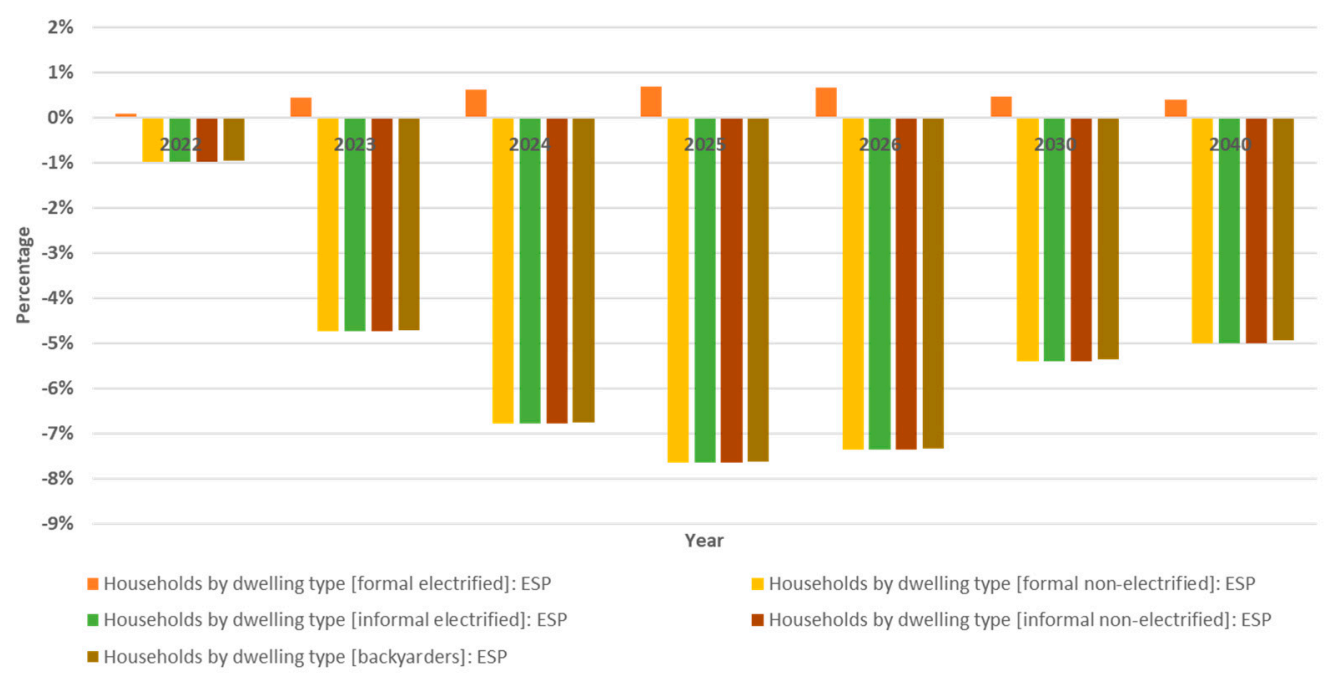

Figure 6. Year-on-year percentage change in households by dwelling type, ESP scenario relative to BAU. Source: Authors.

The implication for urban policy is that the energy subsidy intervention creates attractiveness in the municipality for the households to move to formal electrified dwellings, ultimately generating demand for formal electrified dwellings and increased energy needs. However, ESP does not lead to large changes in formal electrified dwelling households. Further, the intra-dwelling household transition increases the demand for other fuel types, particularly the unclean fuel types, even though the proportion of households in informal dwellings and backyarders declines by 2040. These results indicate that a decline in informal dwellings does not correspond to a decline in the consumption of unclean energy fuel types. Examining the households by dwelling type can be useful in understanding household energy demand behaviours and requirements and can reveal better paths towards a sustainable household energy transition for different households.

\subsection{Changes in Energy Consumption by Fuel Type}

Figure 7 shows the changes in energy consumption by fuel type in the ESP and EPP scenarios. Changes in energy consumption are mainly driven by the changes in households, showing a growing trend for ESP and a declining trend for EEP between 2022 and 2025. An increase in the changes in the use of all energy fuel types occurs 
when the subsidy is introduced because affordability is improved. It also illustrates that urban households generally tend to fuel stack and that improving affordability increases energy consumption of all the different fuel types. The changes shown in Figure 7 also indicate that the household energy services are not fully met with clean energy, hence the consumption of unclean fuels. Although the Drakenstein Municipality statistics indicate a $98.4 \%$ access to electricity, this is not fulfilling the household energy services because grid connection does not equate to fulfilled energy services. However, understanding household characteristics may point to when tipping points may occur for a complete shift from one fuel type to another.

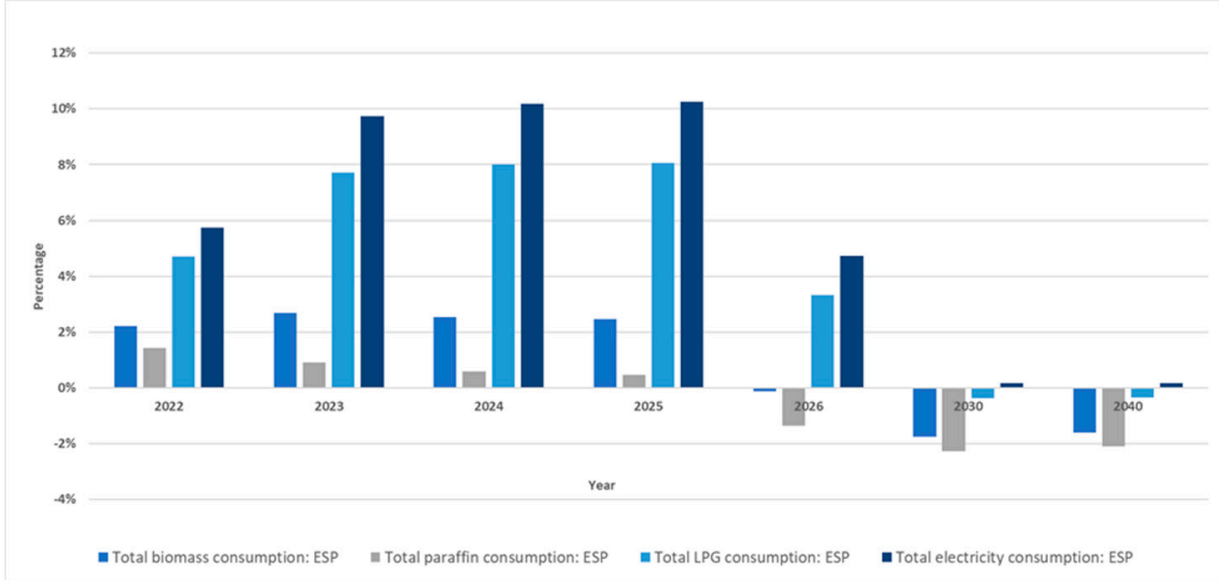

a) ESP scenario

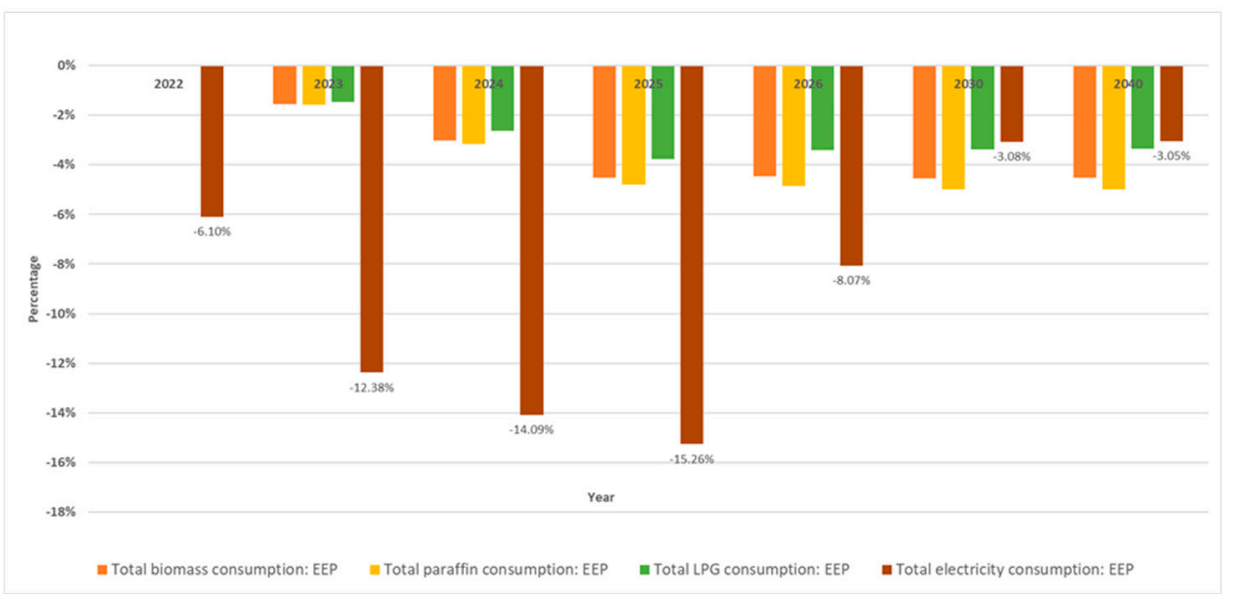

b) EPP scenario

Figure 7. Percentage change in energy consumption by fuel type in the ESP (a) and EPP scenarios (b). Source: Authors.

A key implication for urban planning is shifting from using grid connection as the only indicator for access to sustainable energy for all to exploring composite parameters for household energy services requirements and providing relevant indicators for energy security. Similar to observations by Raven et al. [16], understanding the infrastructure investments concerning households' actions and their social relations that influence information flows about the household energy transition interventions is essential.

This study observed that the ESP tended to benefit electrified households more than those that are not electrified. Biomass consumption was also observed to increase in the informal non-electrified households, categorised by the gender of the household head (Figure 8). The results suggest that the subsidy may exacerbate inequality rather than reduce it. 


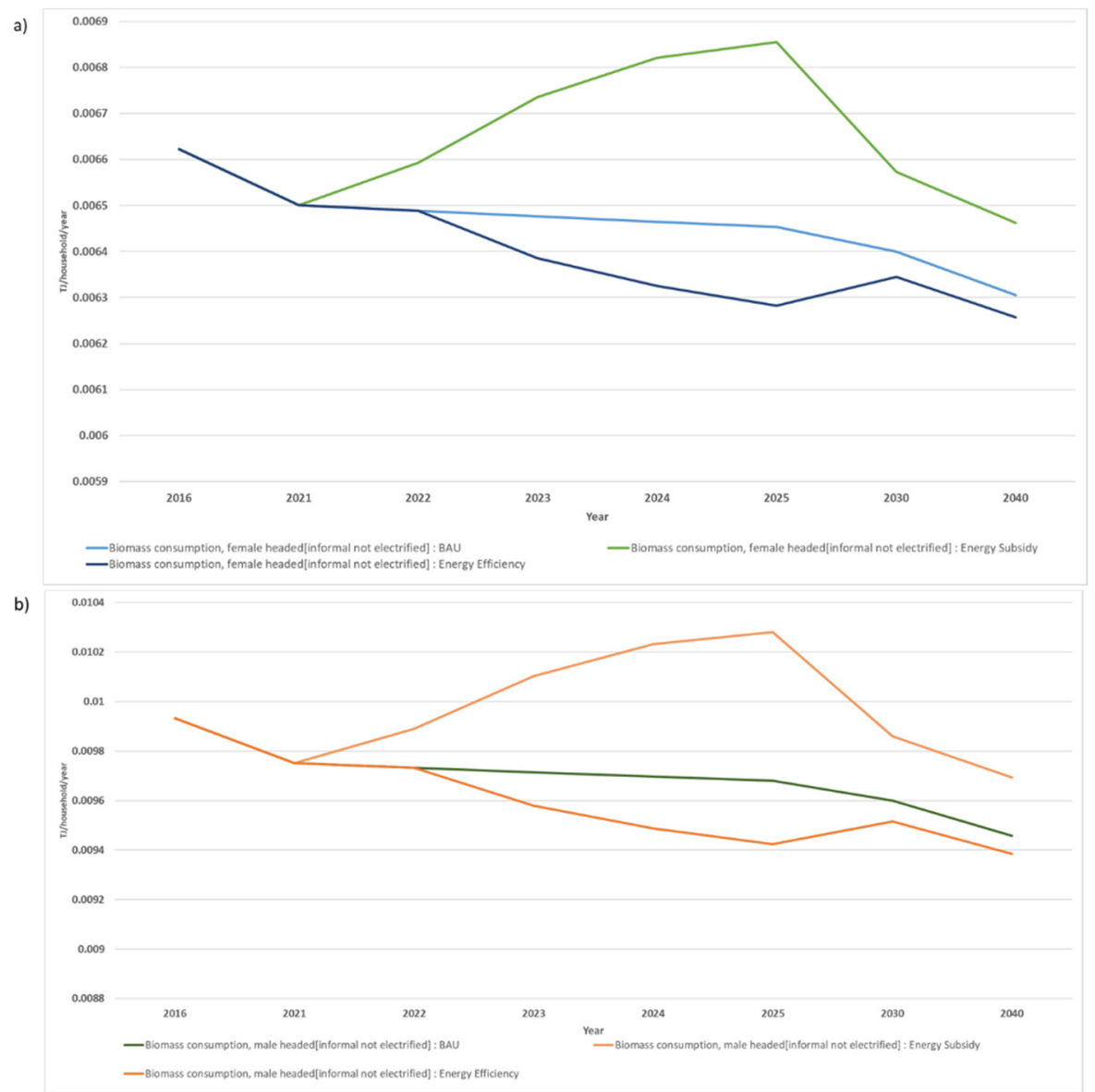

Figure 8. Gendered household biomass energy consumption by dwelling type. Female-headed (a) and Male-headed (b). Source: Authors.

Previous empirical evidence has similarly shown that subsidies increase consumption of the fuel type. For example, in Senegal, LPG was heavily subsidised from 1974 to discourage the use of charcoal with the aim of halving charcoal consumption by 1977; however, consumption of charcoal quadrupled from 2900 to 11,000 tonnes by 1981, and this caused a rise in the black market [41]. Subsidies have little effect on the poor. Similarly, in Indonesia, the retail price of kerosene was reduced by $20 \%$. Surveys later showed that the main beneficiaries were middle-income households, and that there was no evidence that wood fuel consumption or deforestation were reduced [43].

In contrast, the EPP scenario showed a yearly decrease in the use of all fuel types. The largest changes were in total electricity consumption, which was $-15.25 \%$ in 2025 (Figure 7).

\subsection{Changes in Socio-Environmental Impacts}

The major socio-environmental impacts include the social cost of emissions, the cost of fires and health costs related to paraffin use. The main driver of the socio-environmental impacts is energy consumption. Figure 9 shows that the social costs of air emissions increase in the ESP scenario, with the largest change of 9.67\% occurring in 2025 and that costs continue to increase marginally until the end of the simulation period. In contrast, the EEP scenario shows a decrease in both the social cost of air emissions and the cost of fires. 


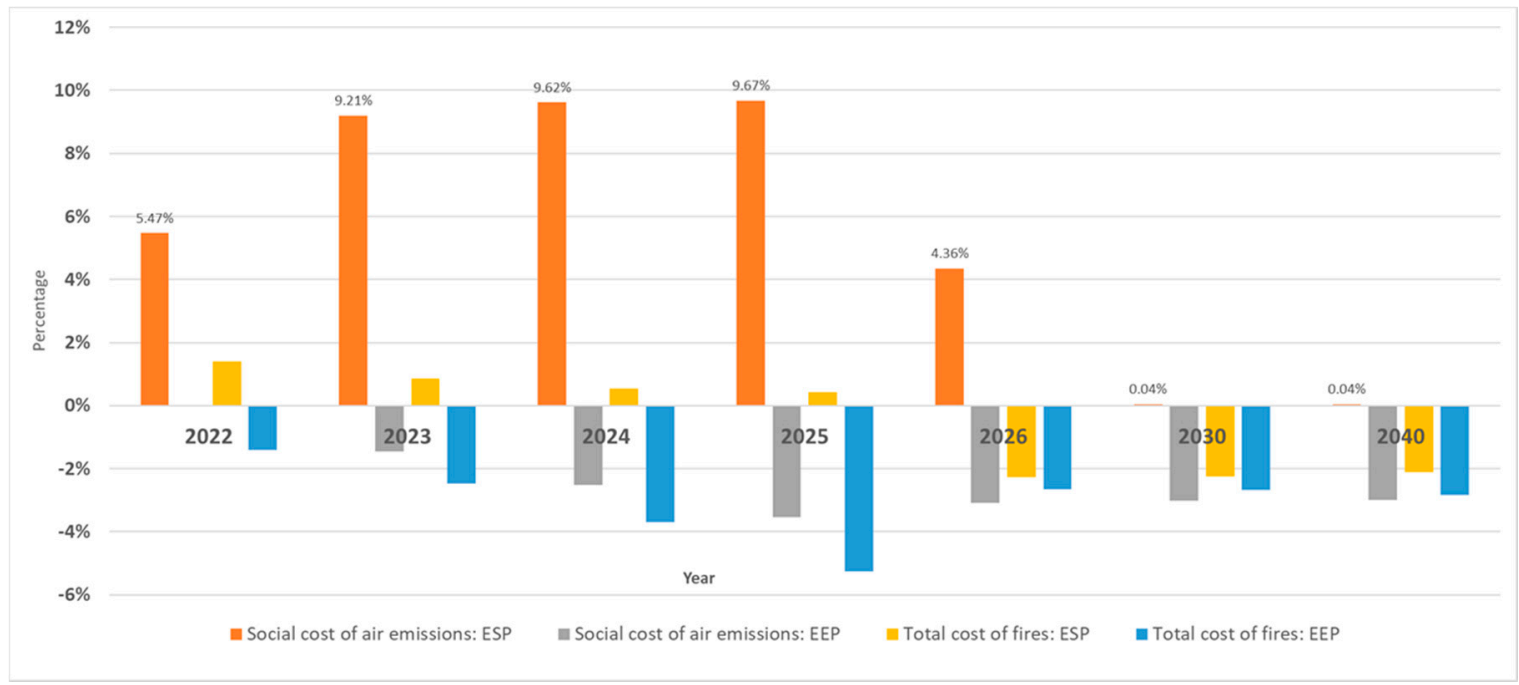

Figure 9. Percentage change in the social cost of air emissions in the ESP and EEP scenarios. Source: Authors.

The changes in the health costs of paraffin use, burns and ingestion show a similar trend, whereby costs increase in the ESP scenario, with the largest changes occurring in 2022 (Figure 10a). The energy efficiency policy shows a decline in the changes related to the health costs of paraffin use, burns and ingestion (Figure 10b).

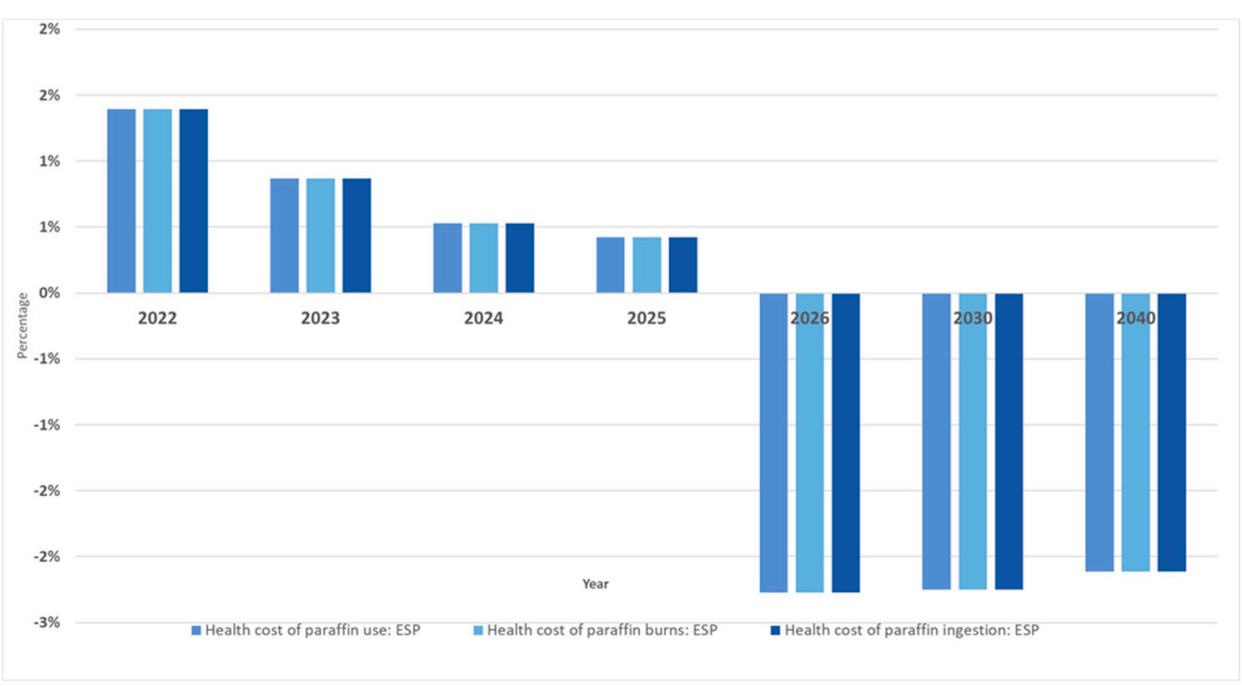

a) ESP scenario

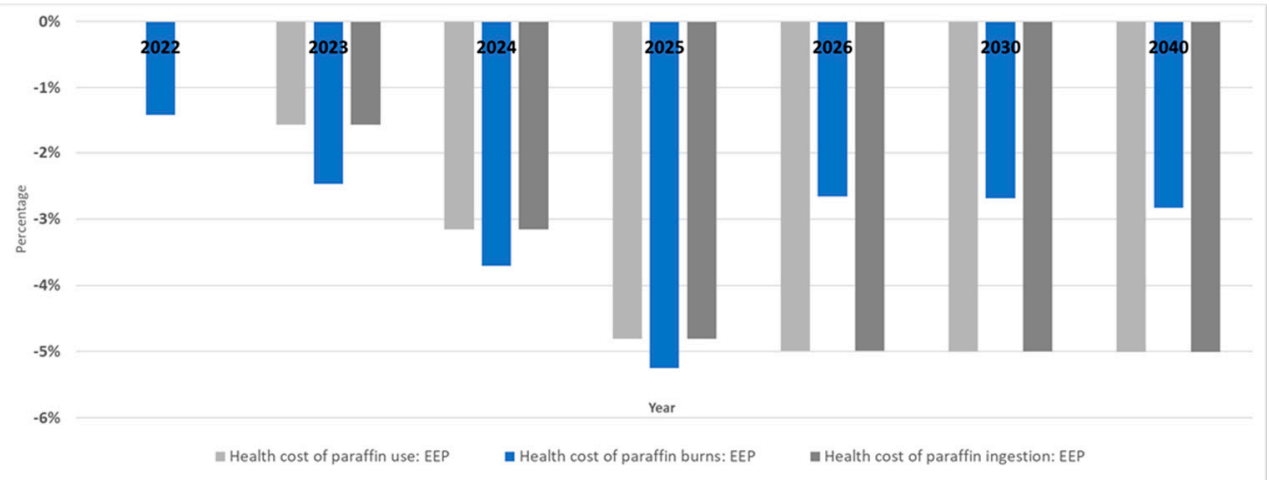

b) EPP scenario

Figure 10. Percentage change in health costs of paraffin fuel, ESP (a) and EPP (b) scenarios. Source: Authors. 
Figures 9 and 10 highlight the concern that some interventions in household energy transition may not be fairer and may result in inequalities. Although the total cost of fires in the ESP decreases the most in 2025, the health costs related to paraffin use, burns and ingestion increase. Overall, the socio-environmental impact with ESP increases due to increased affordability, which reduces costs and increases consumption.

Similar to what was observed by Selvakkumaran and Ahlgren [52], household energy transition processes are not well understood. This study shows that some indicators that rely on energy consumption based on the supply side may not fully represent household behaviours and choices. Additionally, interventions aimed at supporting improvement in achieving energy access for all might result in unintended socio-environmental impacts. The urban household energy transition requires integrating household behaviours and their decision making processes.

\section{Conclusions}

Household energy transitions are relevant in supporting global and national policy agendas related to access to affordable, clean and sustainable energy for all, as well as the transition to a low-carbon economy. However, household energy transition processes are not well understood. In particular, gender is acknowledged as essential in supporting the energy transition. However, there is still a lack of assessment methods that can serve as decision support tools for urban policy makers to inform how their interventions support a gendered energy transition.

This study developed a gendered urban household energy transition (GUHET) model that explored the effect of urban policy interventions, specifically energy subsidies and energy efficiency, on selected energy transition indicators. The model offers an opportunity for debates and discussions on where gender matters in urban household energy transition and whether it is endogenous. This would require a multi-stakeholder engagement process to broaden and deepen our understanding of gender in the energy transition. Also, while the study utilised the case study of Drakenstein Municipality in South Africa, it is expected that the model will be improved continuously and can be customised for assessment in other case studies.

The study contributes to urban household energy transition in several ways. Firstly, in terms of methodology, system dynamics was used to explore the effects of energy transition policy interventions on social, economic and environmental indicators. The model incorporates the cross-sector effects that assess the urban household energy transition as a complex non-linear process evaluated from a policy maker perspective.

Secondly, in terms of results, we find that changes in energy consumption are influenced by policy interventions. However, interventions intended to promote household energy transition may not necessarily be fairer and may exacerbate inequality. Policy responses to support household energy transition have included establishment of grid connection, incentives to minimise use of energy and reduction of energy costs through subsidies and energy efficiency measures. The study results indicate the need to take a holistic approach to support urban energy planning.

Finally, in terms of scope, the urban household energy transition is developed using the case study of Drakenstein Municipality. Although numerous household energy surveys have been conducted, they largely remain as stand-alone assessments. Providing disaggregated gendered household data is relevant for the energy transition because the interventions are influenced by who oversees decision making related to energy purchase and use. Such analysis requires undertaking household surveys to capture detailed information on the household decision making. However, the ability to utilise system dynamics from the perspective of a household captures the household dynamics of the energy transition processes.

Understanding household dynamics is also relevant in supporting the gendered urban household energy transition. It includes capturing information on the gender of the head of 
the household and energy consumption by dwelling type. These characteristics influence household behaviours and energy choices.

This study is not without limitations. First, consideration of gendered energy transition assessment was focused on the gender of the household head. Further exploration of whether and where gender is endogenous or exogenous in the urban household energy transition can improve indicators for evaluation. Second, data from Drakenstein Municipality were not available for all the required parameters. The authors developed a criterion for data collection. Despite the data limitation, the study demonstrated the effects of interventions to inform urban policy on economic, social and environmental indicators. Third, because the study focused on the urban policy maker as the decision maker, most household dynamics that would be relevant when considering the household as the decision maker were not captured. The literature points out different factors that are relevant in urban household energy transition, including (i) behaviour and lifestyle, which influence changes in demand for fuels and technology; (ii) heterogeneity of actors, who are at different stages of the energy transition, which influences the speed of the energy transition; (iii) public acceptance and opposition, which influences the speed of energy transition; (iv) public participation and ownership, which enable people to influence local energy transition; and (v) transformation dynamics, across different time scales. Given the different perspectives, future work will entail taking a systems approach to explore the urban energy transition from the perspective of a household as the decision maker.

Supplementary Materials: The following are available online at https:/ /www.mdpi.com/article/10 $.3390 /$ en14217251/s1, Figure S1: Criteria for input data collection, Table S1: Parameters used in each sub-model and data sources.

Author Contributions: J.K.M.: conceptualization, methodology, formal analysis, writing—original draft preparation. A.M.B.: methodology; writing—review and editing. All authors have read and agreed to the published version of the manuscript.

Funding: This research received no external funding.

Institutional Review Board Statement: Not applicable.

Informed Consent Statement: Not applicable.

Acknowledgments: This research contributes to the Africa-UK Trilateral Research Chair ID SARCI11 8076349612, under the Newton Fund-National Research Foundation of South Africa Partnership, Grant Number 120129.

Conflicts of Interest: The authors declare no conflict of interest.

\section{References}

1. International Energy Agency. Net Zero by 2050: A Roadmap for the Global Energy Sector. Available online: https:/ iea.blob.core. windows.net/assets / 4482cac7-edd6-4c03-b6a2-8e79792d16d9/NetZeroby2050-ARoadmapfortheGlobalEnergySector.pdf (accessed on 31 May 2021).

2. Cajot, S.; Peter, M.; Bahu, J.-M.; Koch, A.; Marechal, F. Energy planning in the urban context: Challenges and perspectives. Energy Procedia 2015, 78, 3366-3371. [CrossRef]

3. Cajot, S.; Peter, M.; Bahu, J.-M.; Guignet, F.; Koch, A.; Marechal, F. Obstacles in energy planning at the urban scale. Sustain. Cities Soc. 2017, 30, 223-236. [CrossRef]

4. Miller, C.A.; Iles, A.; Jones, C.F. The social dimensions of energy transitions. Sci. Cult. 2013, 22, 135-148. [CrossRef]

5. Intergovernmental Panel on Climate Change. Renewable Energy Sources and Climate Change Mitigation: Summary for Policymakers and Technical Summary. Available online: https://www.ipcc.ch/site/assets/uploads/2018/03/SRREN_FD_SPM_ final-1.pdf (accessed on 2 June 2021).

6. Sovacool, B.K.; Geels, F.W. Further reflections on the temporality of energy transitions: A response to critics. Energy Res. Soc. Sci. 2016, 22, 232-237. [CrossRef]

7. Blazquez, J.; Fuentes, R.; Manzano, B. On some economic principles of the energy transition. Energy Policy 2020, 147, 111807. [CrossRef]

8. Gebreegziabher, Z.; Mekonnen, A.; Kassie, M.; Köhlin, G. Urban energy transition and technology adoption: The case of Tigrai, northern Ethiopia. Energy Econ. 2012, 34, 410-418. [CrossRef] 
9. García-García, P.; Carpintero, Ó.; Buendía, L. Just energy transitions to low-carbon economies: A review of the concept and its effects on labour and income. Energy Res. Soc. Sci. 2020, 70, 101664. [CrossRef]

10. Musango, J.K.; Brent, A.C. A conceptual framework for energy technology sustainability assessment. Energy Sustain. Dev. 2011, 15, 84-91. [CrossRef]

11. Sovacool, B.K. How long will it take? Conceptualizing the temporal dynamics of energy transitions. Energy Res. Soc. Sci. 2016, 13, 202-215. [CrossRef]

12. Geels, F.W. From sectoral systems of innovation to socio-technical systems: Insights about dynamics and change from sociology and institutional theory. Res. Policy 2004, 33, 897-920. [CrossRef]

13. Lieu, J.; Sorman, A.H.; Johnson, O.W.; Virla, L.D.; Resurrección, B.P. Three sides to every story: Gender perspectives in energy transition pathways in Canada, Kenya and Spain. Energy Res. Soc. Sci. 2020, 68, 101550. [CrossRef]

14. Musango, J.K.; Smit, S.; Ceschin, F.; Ambole, A.; Batinge, B.; Anditi, C.; Petrulaityte, A.; Mukama, M. Mainstreaming gender to achieve security of energy services in poor urban environments. Energy Res. Soc. Sci. 2020, 70, 101715. [CrossRef]

15. Musango, J.K.; Currie, P.; Smit, S.; Kovacic, Z. Urban metabolism of the informal city: Probing and measuring the 'unmeasurable' to monitor Sustainable Development Goal 11 indicators. Ecol. Indic. 2020, 119, 106746. [CrossRef]

16. Raven, R.; Reynolds, D.; Lane, R.; Lindsay, J.; Kronsell, A.; Arunachalam, D. Households in sustainability transitions: A systematic review and new research avenues. Environ. Innov. Soc. Transit. 2021, 40, 87-107. [CrossRef]

17. World Energy Council. World Energy Trilemma Index 2020. Available online: https://www.worldenergy.org/assets/downloads/ World_Energy_Trilemma_Index_2020_-_REPORT.pdf (accessed on 24 August 2021).

18. Batinge, B.; Musango, J.K.; Ceschin, F.; Ambole, A.; Smit, S.; Petrulaityte, A. Modelling gendered innovation for the security of energy services in poor urban environments. Syst. Res. Behav. Sci. 2021. Available online: https://onlinelibrary-wiley-com.ez. sun.ac.za/doi/10.1002/sres.27939 (accessed on 25 October 2021).

19. World Bank. World Bank Databank. Available online: http:/ / data.worldbank.org/ (accessed on 16 July 2021).

20. Naill, R.F. Managing the Energy Transition: A System Dynamics Search for Alternatives to Oil and Gas. [COAL2 Model]; Ballinger Publishing Co: Pensacola, FL, USA, 1977.

21. Selvakkumaran, S.; Ahlgren, E.O. Review of the use of system dynamics (SD) in scrutinizing local energy transitions. J. Environ. Manag. 2020, 272, 111053. [CrossRef]

22. Destyanto, A.R.; Silalahi, T.D.; Hidayatno, A. Exploration of government policy structure which support and block energy transition process in Indonesia using system dynamics model. IOP Conference Series: Earth Environ. Sci. 2017, $94,012155$. [CrossRef]

23. Musango, J.K. A system dynamics approach to understand gendered energy innovations in poor urban environments. Sustainability 2021. Forthcoming.

24. Fell, M.J. Energy services: A conceptual review. Energy Res. Soc. Sci. 2017, 27, 129-140. [CrossRef]

25. Sovacool, B.K. Security of energy services and uses within urban households. Curr. Opin. Environ. Sustain. 2011, 3, 218-224. [CrossRef]

26. Haas, R.; Nakicenovic, N.; Ajanovic, A.; Faber, T.; Kranzl, L.; Müller, A.; Resch, G. Towards sustainability of energy systems: A primer on how to apply the concept of energy services to identify necessary trends and policies. Energy Policy 2008, 36, $4012-4021$. [CrossRef]

27. Western Cape Provincial Government. Socioeconomic Profile: Drakenstein Municipality. 2018. Available online: https: / / www.westerncape.gov.za/provincial-treasury / files/atoms/files/WC023\%202019\%20Socio-economic\%20Profile\%20 -\%20Drakenstein\%20Municipality.pdf (accessed on 8 June 2021).

28. Sustainable Energy Africa. State of South African Cities 2020. Available online: https://www.cityenergy.org.za/wp-content/ uploads/2021/02/resource_508.pdf (accessed on 26 August 2021).

29. Marais, L.; Cloete, J. The role of secondary cities in managing urbanisation in South Africa. Dev. South. Afr. 2017, 34, 182-195. [CrossRef]

30. UN-Habitat. State of the World Cities 2010/2011: Bridging the Urban Divide. 2010. Available online: https:/ / unhabitat.org/ state-of-the-worlds-cities-20102011-cities-for-all-bridging-the-urban-divide (accessed on 24 August 2021).

31. Drakenstein Municipality. Integrated Development Plan, 2017-2022. Available online: http://www.drakenstein.gov.za/docs/ Documents/FINAL\%202017-2022\%20IDP\%20Drakenstein\%20Municipality.pdf (accessed on 23 June 2021).

32. Drakenstein Municipality. Drakenstein Integrated Economic Growth Strategy. Available online: http://www.drakenstein.gov.za/ docs/Documents / Drakenstein\%20Integrated\%20Economic\%20Growth\%20Strategy.pdf (accessed on 1 August 2021).

33. South African Government. Municipalities of South Africa: Drakenstein Local Municipality (WC023). Available online: https://municipalities.co.za/demographic/1208/drakenstein-local-municipality (accessed on 26 July 2021).

34. Musango, J.K.; Energy and Gender in South Africa. Virtual Workshop Report. 24 March 2021. Available online: https: / / gens.sun.ac.za/resources (accessed on 25 October 2021).

35. Drakenstein Municipality. Tariff Book 2020/2021. Available online: http://www.drakenstein.gov.za/docs/Documents/3.\%2 0Tariff\%20List\%202020-2021.pdf (accessed on 24 August 2021).

36. GreenCape. Market Intelligence Report 2021. Available online: https://www.greencape.co.za/assets/Energy_Services_MIR_20 21_31_3_21.pdf (accessed on 19 August 2021). 
37. Kowsari, R.; Zerriffi, H. Three-dimensional energy profile: A conceptual framework for assessing household energy use. Energy Policy 2011, 39, 7505-7517. [CrossRef]

38. Wang, Q.; Lin, J.; Zhou, K.; Fan, J.; Kwan, M.-P. Does urbanization lead to less residential energy consumption? A comparative study of 136 countries. Energy 2020, 202, 117765. [CrossRef]

39. Bassi, A.M. Tackling the Complexity of Energy Demand and Support Measures. International Institute for Sustainable Development (IISD) and WWF. In Press. Available online: https: / / www.taylorfrancis.com/books/mono/10.4324/9781351287647/ tackling-complexity-gilbert-probst-andrea-bassi (accessed on 12 October 2021).

40. Western Cape Government. Provincial Strategic Plan, 2014-2019. Available online: https://www.westerncape.gov.za/text/2015 /October/western_cape_provincial_strategic_plan_2014-2019.pdf (accessed on 24 August 2021).

41. Leach, G. The energy transition. Energy Policy 1992, 20, 116-123. [CrossRef]

42. Hosier, R.H.; Dowd, J. Household fuel choice in Zimbabwe: An empirical test of the energy ladder hypothesis. Resour. Energy 1987, 9, 347-361. [CrossRef]

43. Statistics South Africa. Mid-Year Population Estimates. Available online: http://www.statssa.gov.za/publications/P0302/P030 22020.pdf (accessed on 15 July 2021).

44. Schunder, T.; Bagchi-Sen, S. Understanding the household cooking fuel transition. Geogr. Compass 2019, 13, e12469. [CrossRef]

45. Ajayi, P.I. Urban household energy demand in southwest Nigeria. Afr. Dev. Rev. 2018, 30, 410-422. [CrossRef]

46. World Health Organization. Household Air Pollution and Health. Available online: https://www-who-int.ez.sun.ac.za/newsroom/fact-sheets/detail/household-air-pollution-and-health (accessed on 24 August 2021).

47. Barnes, D.F.; Krutilla, K.; Hyde, W.F. The Urban Household Energy Transition: Social and Environmental Impacts in the Developing World; Resources for the Future: Washington, WA, USA, 2005; pp. 13-26.

48. Oparaocha, S.; Dutta, S. Gender and energy for sustainable development. Curr. Opin. Environ. Sustain. 2011, 3, 265-271. [CrossRef]

49. Bianco, V.; Sonvilla, P.M. Supporting energy efficiency measures in the residential sector: The case of on-bill schemes. Energy Rep. 2021, 7, 4298-4307. [CrossRef]

50. International Renewable Energy Agency. Energy Subsidies: Evolution in the Global Energy Transformation to 2050. Available online: https:/ / www.irena.org/-/media/Files/IRENA/Agency/Publication/2020/Apr/IRENA_Energy_subsidies_2020.pdf (accessed on 24 August 2021).

51. Kovacic, Z.; Musango, J.K.; Ambole, L.A.; Buyana, K.; Smit, S.; Anditi, C.; Mwau, B.; Ogot, M.; Lwasa, S.; Brent, A.C.; et al. Interrogating differences: A comparative analysis of Africa's informal settlements. World Dev. 2019, 122, 614-627. [CrossRef]

52. Selvakkumaran, S.; Ahlgren, E.O. Determining the factors of household energy transitions: A multi-domain study. Technol. Soc. 2019, 57, 54-75. [CrossRef] 